\title{
THEORETICAL INVESTIGATION INTO A PRESSURE WAVE SUPERCHARGER
}

\author{
A. H. El-Askary, S. A .Wilson, A .R .Syam, K.A.Omara \\ Mechanical Power Engineering Dept., Faculty of Engineering (Shebin El-Kom), Menoufiya \\ University, Shebin El-Kom, 32511, Egypt \\ Emails:prof_dr_aelaskary@yahoo.com, safwatwilson@gmail.com, \\ awad_syam@yahoo.com,eng_kareem73@yahoo.com
}

\begin{abstract}
Pressure wave supercharger (PWS) is widely used in different applications especially for charging the internal combustion engines. This device utilizes the pressure waves issued the exhaust manifold. These waves transmitted from the exhaust gas side to the air side causing compression effect required for charging process. The present work aims to build a mathematical model to address the behavior of PWS at a wide range of operating conditions. The proposed model employs the basic conservation equations of continuity, momentum and energy as well as the species transportation. The gas flow is treated as $1-\mathrm{D}$, time dependent, and non-reactive compressible fluid flow. These equations are solved together numerically by using two steps LaxWendroff scheme. This technique enables to simulate the pressure waves more accurately and precisely. A computer code has been built to simulate the effect of many parameters on PWS performance. These parameters are dimensions and cells size, number of cells, rotational speed of PWS, engine speed and the exhaust gas pressure. Synchronization between the engine speed and PWS speed requires mathematical coupling between the engine cycle and PWS. Therefore, real cycle simulation is performed taking into consideration combustion processes, valve timing, and the amount of residual gases. The results of the present model are compared with another data to validate the model. The comparison shows fair agreement. Using PWS with internal combustion engines leads to enhancing the engine power, volumetric efficiency and reducing NOx emissions.
\end{abstract}

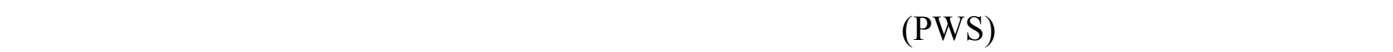

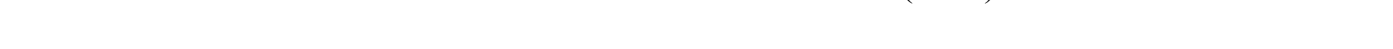

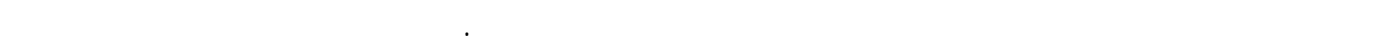

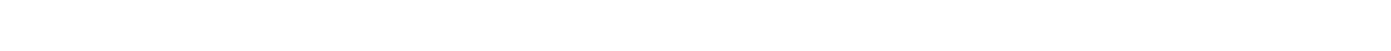

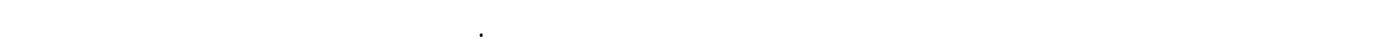

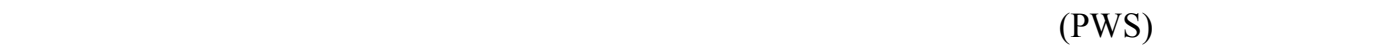

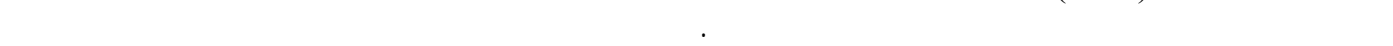

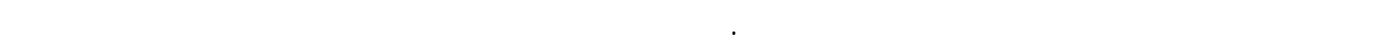

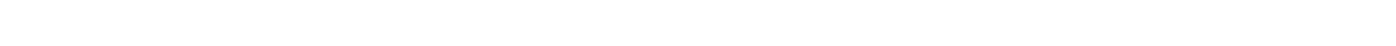

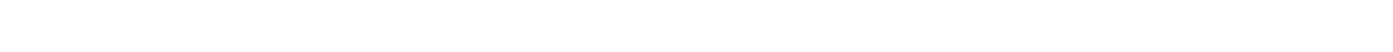

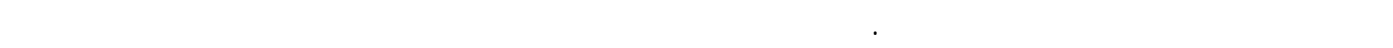

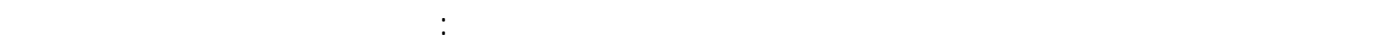

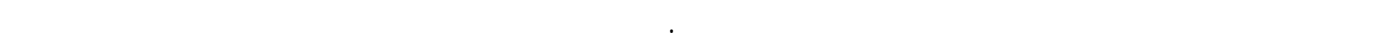

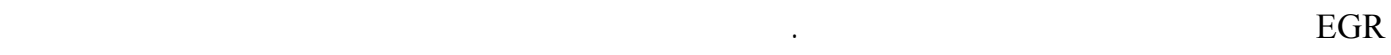

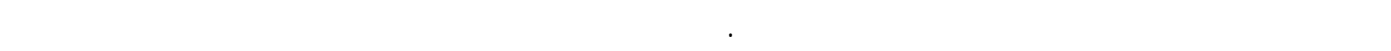

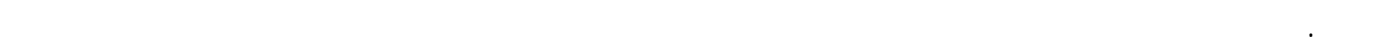
الضارة.

Keywords: compression ignition engine, pressure wave supercharger, exhaust gas recirculation, supercharging 


\subsection{Introduction}

Pressure wave supercharger (PWS) technology has shown unique capabilities to enhance the performance and operating characteristics of a variety of engines. The pressure wave supercharger is an alternative charging device for the internal combustion engines. Its principle depends on the physical fact that if two gases of different pressures are brought into direct contact, pressure equalization is faster than mixing process. A wave rotor is an array of channels arranged around the axis of a cylindrical drum. The drum rotates between two stationary plates, each of which has a few ports and manifolds, controlling the gases flow through the channels. During rotation, the channel ends are periodically exposed to differing port pressures, creating a compression, and expansion waves within the wave rotor channels. Careful in selecting their locations and widths is essential to generate and utilize the wave action. A significant and efficient transfer of energy is then obtained between the two gases flow in the connected ducts. The gap between the casing and the rotor has to be very small, in order to minimize leakage. Referring to Fig 1 PWS can be divided into two main parts; the high-pressure part and the low-pressure part. The exhaust gas enthalpy at the entry of channel 3 (ch3) is used for charging the compression of the fresh air in channel $2(\mathrm{ch} 2)$. The target of the low-pressure part is to scavenging the exhaust gases and air which still in the cell towards the exhaust port (channel 4 (ch4)) and to fill it up again with fresh air from channel 1 (ch1). Under normal operating conditions, channel $4(\operatorname{ch} 4)$ is not only filled with exhaust gases, but also with apart of fresh air that was compressed in the high-pressure zone, but did not flow into channel 2 (ch2). On the other hand some of exhaust gases mixes with air entering the engine combustion chamber which is defined as exhaust gas recirculation (EGR).This amount of EGR prevent excessive temperature during combustion and consequently, reduces emission of (NOx) [1]. Doerfler and Berchtold [2] are considered to be the first to manufacture and test the PWS on vehicle powered by diesel engines successfully. As a result of their success, a cooperative program between those researchers and Brown Boveri Company (BBC) was started in 1955. In the 1970s, the first prototypes were installed on truck engines, and other types of vehicles [2, 4]. On the other hand the PWS device has been also installed on spark-ignition engines in order to examine its usefulness to lower the fuel consumption and to improve its drivability [1]. One of the most important trials to simulate the PWS performance is proposed by Spring et al [5, 6]. Using a model employs Eulerins form of conservation law in one dimensional, time dependent domains. The model considered the gas leakage between the rotor clearance as well as the heat transferred through PWS casing. The differential equations are solved simultaneously by using Lax-Wendroff technique. Hewedy et al [7] studied the moving rarefaction wave towards a gradual convergent area duct to produce a flow that moves in the opposite direction of the wave motion. The numerical solution, based on Lax-Wendroff scheme and characteristic method at boundaries, has been used to solve the governing equations of unsteady, one dimensional, inviscid perfect gas flow. In the present study the PWS is applied in compression ignition engines to examine its performance. The object of the present work is to investigate the behavior of PWS at different operating conditions and how it affects the performance, efficiency and emissions.

Synchronization between the PWS and engine speed is considered also in the present model. The process occurs inside PWS is illustrated in figures. (1 and 2). These figures show the transmission of the pressure of the exhaust gases coming from the exhaust manifold to the fresh air entering the intake manifold. Numerous factors were found to be effective in designing the PWS, (see Fig.(2)), such as cells size. The other dimensions of the wave rotor such as rotor width, inner and outer diameter share with the pressure to construct the shape of the pressure waves. The PWS rotational speed was taken $12000 \mathrm{rpm}$ in the present work. This enables PWS to complete two cycles for each exhaust process considering the engine runs at $3000 \mathrm{rpm}$ (capacity $=942 \mathrm{~cm}^{3}$ and compression ratio=16). Diffusion of the exhaust gases and the fresh air was studied to compute the speed range at which the exhaust gases may found in fresh air and may enter the engine (EGR). The rotor runs inside a fixed casing have many ports as shown in Figure (1) for gases exchange process. Opening and closing periods of each port are illustrated in Fig.(3). These periods control the charging and discharging processes inside the rotor cells by the air and the exhaust gases. The effective cross section area of ports at inlet or outlet is considered when solving the complete cycle of PWS. Synchronization between the engine speed and PWS speed required the engine cycle to be mathematically simulated. In the engine cycle many parameters were taken into account such as combustion process, valve timing, and amount of residual gases. These parameters draw the pressure distribution. Synchronization of engine speed with PWS speed enables in studying the effect of PWS on engine performance. Fresh air compressed to high pressure which increases the amount of charge entering the engine combustion chamber, this in turn increases the power and the efficiency of the engine.

\subsection{Supercharged engine thermodynamics cycle}

The mathematical solution of the engine thermodynamics cycle employs the coupling between 
the engine thermal cycle and the PWS. The solution of the engine thermodynamics cycle represents the input data to the PWS simulation. In present case study, the engine operates at $3000 \mathrm{rpm}$ with cylinder of $100 \mathrm{~mm}$ diameter, beginning of injection $20^{\circ} \mathrm{C}$.A before TDC, and beginning of exhaust $20^{\circ}$ to $40^{\circ}$ C.A after TDC. Exhaust process begins with blow down process at which the gas pressure is relatively high. Where the piston reaches BDC, the positive scavenging of the exhaust gases begins at lower pressure corresponded to blow down process. These two distance pressure zones affect the gas exchange inside PWS as show in the following section (Fig.4).

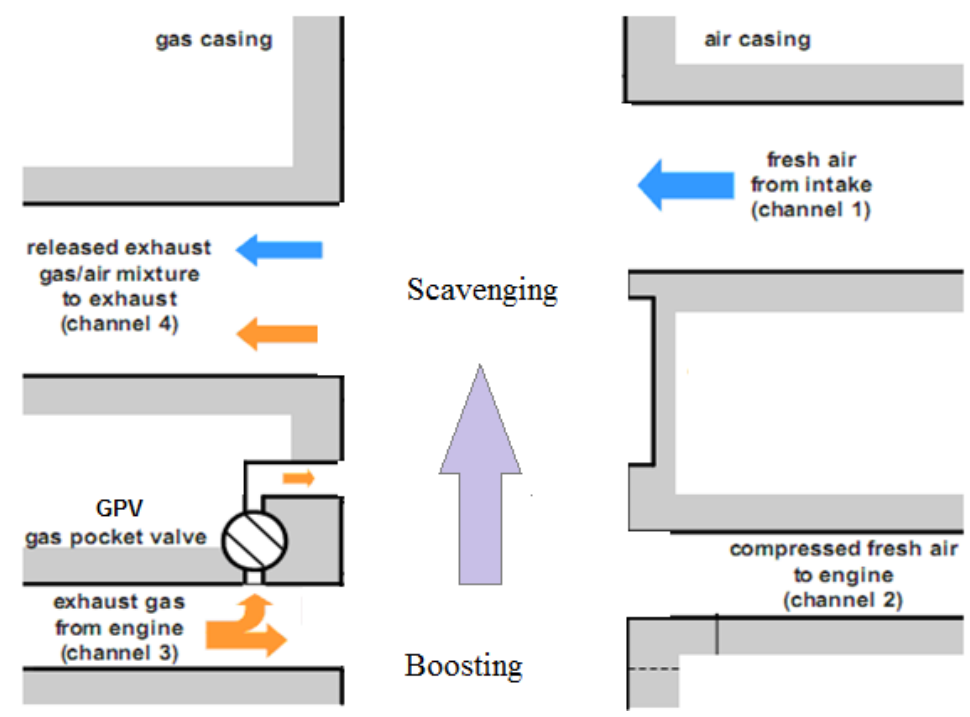

Fig.1 Mechanism of PWS operation

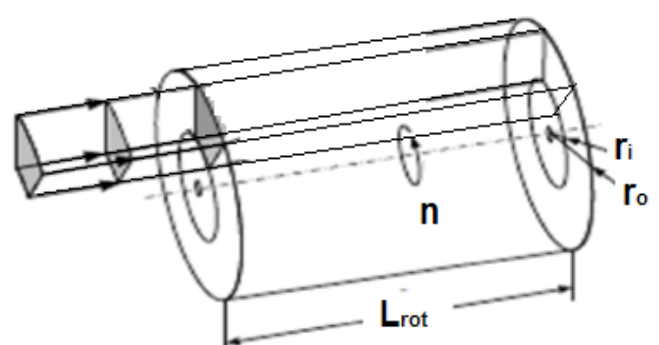

Fig.2 Basic dimensions of PWS $\left(n_{P W S}=12000 \mathrm{rpm}, L_{\text {rot }}=120 \mathrm{~mm}, r_{0}=120 \mathrm{~mm}, r_{i}=100 \mathrm{~mm}\right.$, Height $=$ width $=10$ $\mathrm{mm}$ and number of cell=20)

\subsection{Modeling of pressure wave supercharger}

In the present proposed model, the gas flowing through the rotor cells is treated as one dimensional, time dependent, non-reactive and compressible flow. The gas leakage through rotor clearance, exhaust heat losses and friction losses were taken into consideration. During its motion through the rotor cells, the gas is bounded by inlet and exit sections with variable cross section area and side walls as shown in Fig. (2).
Three of side walls forming the gas passage have a rotational motion, which the upper wall is fixed. The variation in the inlet and the exit cross section areas comes from the relative motion of rotor cells with respect to fixed inlet and exit ports. The instantaneous inlet and exit cross section areas and their opening and closing timing are illustrated in Fig (3). The mathematical model represents of such boundary conditions will be considered in the following section. 


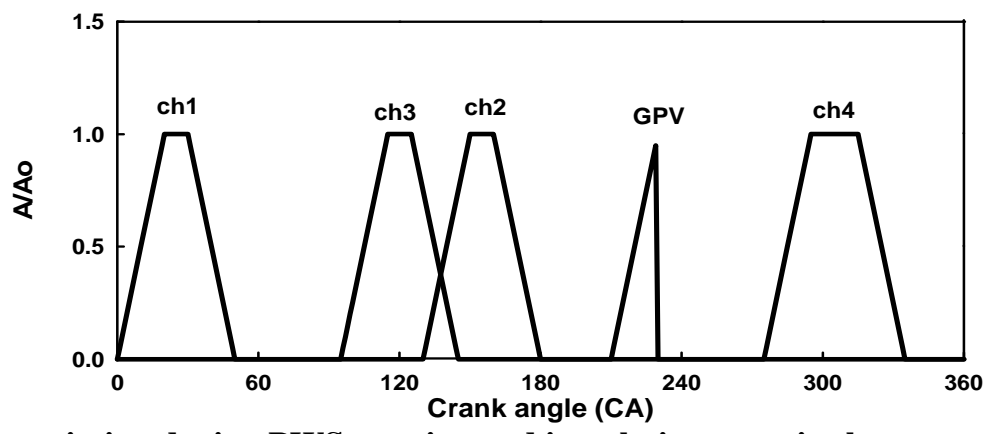

Fig.3 Ports timing during PWS rotation and its relative areas in the present code

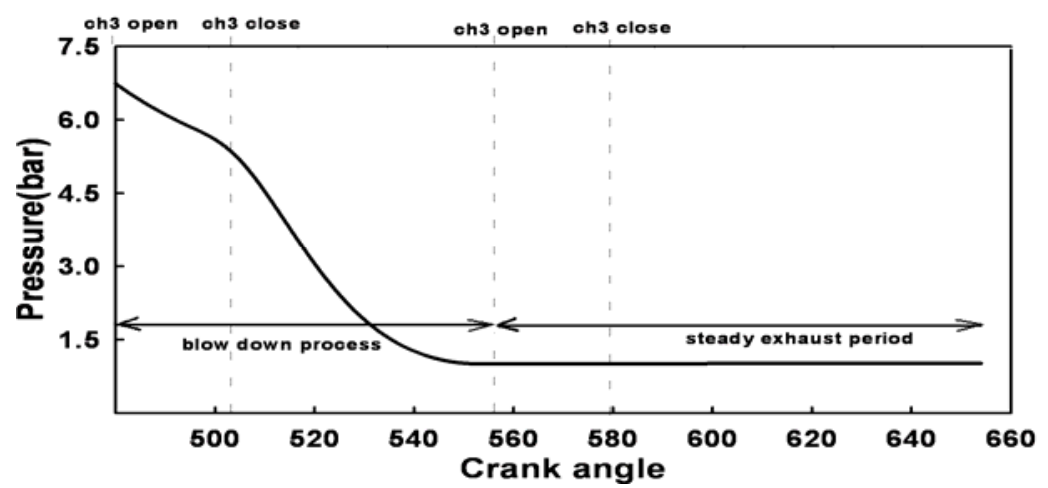

Fig.4 Schematic overview of the exhaust gas process for CIE of compression ratio =16, four stroke, cylinder diameter=100 mm, stroke length=120 mm and speed=3000 rpm in the present code.

Two steps Lax-Wendroff method is employed as a numerical technique to solve the differential equations of the present model, which proven to be more stable in solving such problems. This model also includes solving of engine thermodynamic cycle to get exhaust gases that will be the source of the pressure waves.

\subsection{Assumptions and governing equations}

In order to simulate the unsteady processes taking place inside the cell wheel, the physics of the processes of compression and expansion are considered. Dimensional unsteady flow inside PWS will be used. Also some effects have to be taken into account such as the finite width of cells and the processes of opening and closing the cell. Hot exhaust gases entering the cell transfer some energy to the colder rotor walls, while the cold fresh air is heated up by the wall. In the gap between the static casing and the rotating cell wheel, a leakage mass flow must be expected. Heat transfer and friction will be taken into account. The species exchange between the exhaust gases and air will be solved in order to study the diffusion between gases and air. All these physical phenomena have to be modeled mathematically. The conservation equations of mass, momentum as well as energy and the equation of state are used as follows [6].

Conservation of mass:

$$
\frac{\partial \rho}{\partial \mathrm{t}}+\frac{\partial(\rho \mathrm{u})}{\partial \mathrm{x}}=0
$$

Conservation of momentum:

$\frac{\partial \rho}{\partial t}+\frac{\partial\left(\rho u^{2}\right)}{\partial x}+\frac{\partial p}{\partial x}=0$

Conservation of energy:

$$
\frac{\partial\left(\mathrm{pe}_{\mathrm{T}}\right)}{\partial \mathrm{t}}+\frac{\partial\left(\rho_{\mathrm{e}}\right)}{\partial \mathrm{x}}+\frac{\partial(\mathrm{pu})}{\partial \mathrm{x}}=0
$$

Equation of state:

$$
\mathrm{P}=\rho \mathrm{RT}
$$

Caloric equation of state:

$$
\mathrm{e}=\mathrm{C}_{\mathrm{v}} \mathrm{T}=\frac{\mathrm{R}}{\mathrm{k}-1} \mathrm{~T}
$$

Total internal energy as follows:

$$
\mathrm{e}_{\mathrm{T}}=\mathrm{e}+\frac{\mathrm{u}^{2}}{2}=\frac{1}{\mathrm{k}-1} \frac{\mathrm{P}}{\rho}+\frac{\mathrm{u}^{2}}{2}
$$

The local concentration of exhaust gas species inside the channels is calculated by using the transport equation for non-reactive flow as follows:

$$
\frac{\partial \rho y_{i}}{\partial t}+\frac{\partial \rho u y_{i}}{\partial x}=\frac{\partial}{\partial x}\left(D_{i m} \frac{\partial y_{i}}{\partial x}\right)
$$


Where:

The effective diffusion coefficient $D_{\text {im }}$ for species $i$ in the mixture depends on the binary diffusion coefficient of each species relative to each other as follows.

$D_{i m}=\frac{(1-x)}{\sum\left(x / D_{i}\right)} \Rightarrow i=1,2,3, \ldots . . n$

The basic reaction during combustion process is as follows:

$$
\begin{aligned}
& \mathrm{C}_{\mathrm{n}} \mathrm{H}_{\mathrm{m}}+\left[\mathrm{n}+\frac{\mathrm{m}}{4}\right] \lambda\left(\mathrm{O}_{2}+3.76 \mathrm{~N}_{2}\right) \rightarrow \\
& \mathrm{nCO}_{2}+\frac{\mathrm{m}}{2} \mathrm{H}_{2} \mathrm{O}+\left(\mathrm{n}+\frac{\mathrm{m}}{4}\right)(\lambda-1) \mathrm{O}_{2}+3.76 \lambda\left(\mathrm{n}+\frac{\mathrm{m}}{4}\right) \mathrm{N}_{2}
\end{aligned}
$$

Where $\mathrm{n}$ and $\mathrm{m}$ are the numbers of carbon and hydrogen atoms.

The formation of $\mathrm{NO}$ is modeled as follows:

$\mathrm{N}_{2}+\mathrm{O}_{2} \rightarrow 2 \mathrm{NO}$

The concentration of $\mathrm{NO}$ is estimated at equilibrium condition as follow:

$$
\mathrm{K}_{\mathrm{P}}=\frac{\left(\frac{P_{N O}}{P_{T}}\right)^{2}}{\left(\frac{P_{O 2}}{P_{T}}\right)\left(\frac{P_{N 2}}{P_{T}}\right)}
$$

The equilibrium constant is calculated via the Gibbs function $\left(\Delta \mathrm{G}_{\mathrm{T}}\right)$ as follow:

$$
\mathrm{K}_{\mathrm{P}}=\exp \left(-\Delta \mathrm{G}_{\mathrm{T}}^{0} / \mathrm{R}_{\mathrm{u}} \mathrm{T}\right)
$$

The conservation laws equations is summarized in compact Eulerins form as follows:

$$
\frac{\partial \mathrm{U}}{\partial t}+\frac{\partial F}{\partial x}=0
$$

Where:

$$
\begin{aligned}
& \mathrm{U}=f\left[\rho, \rho \mathrm{u}, \rho \mathrm{e}_{\mathrm{T}}\right] \\
& \mathrm{F}=f\left[\rho \mathrm{u}, \rho \mathrm{u}^{2}+\mathrm{P}, \rho \mathrm{ue}_{\mathrm{T}}+\mathrm{Pu}\right]
\end{aligned}
$$

When considering the losses as heat transfer, leakage and friction then equation (2-13) becomes:

$$
\frac{\partial \mathrm{U}}{\partial t}+\frac{\partial F}{\partial x}+\mathrm{B}=0
$$

Where

$$
\mathrm{B}=f\left(\frac{\mathrm{m}_{\mathrm{le}}}{\mathrm{A}_{\mathrm{c}} \mathrm{dx}}, \rho \mathrm{f}_{\mathrm{fr}}+\mathrm{u} \frac{\mathrm{m}_{\mathrm{le}}}{\mathrm{A}_{\mathrm{c}} \mathrm{dx}}, \frac{-\mathrm{Q}_{\mathrm{co}}}{\mathrm{A}_{\mathrm{c}} \mathrm{dx}}+\mathrm{e}_{\mathrm{T}} \frac{\mathrm{m}_{\mathrm{le}}}{\mathrm{A}_{\mathrm{c}} \mathrm{dx}}\right)
$$

Leakage occurs in the gap between the cell wheel and the casing from both left and right side is represented by the following equation [13]:

$$
\dot{\mathrm{m}}_{\mathrm{le}}=\mathrm{C}_{\mathrm{d}} \mathrm{A}_{\text {geo }} \sqrt{\mathrm{P}_{\text {up }} \mathrm{P}_{\mathrm{do}}} \sqrt{\frac{2 \mathrm{k}}{\mathrm{k}-1}} \sqrt{\left(\frac{\mathrm{P}}{\mathrm{P}_{\mathrm{O}}}\right)^{\frac{2}{\mathrm{k}}}-\left(\frac{\mathrm{P}}{\mathrm{P}_{\mathrm{O}}}\right)^{\frac{\mathrm{k}+1}{\mathrm{k}}}}
$$

The specific friction $f_{f r}$ is computed using the following equation [13]:

$$
\mathrm{f}_{\mathrm{fr}}=\mathrm{C}_{\mathrm{fr}} \frac{\mathrm{u}|\mathrm{u}|}{2} \frac{1}{\mathrm{D}_{\mathrm{c}}}
$$

Where $\mathrm{u}$ is the gas velocity, Dc is the hydraulic diameter of the control volume, and $\mathrm{C}_{\mathrm{fr}}$ is the friction coefficient and equal 0.002[4]. Convective heat transfer from fluid to wall of the boundaries of the control volume is represented as follows:-

$\mathrm{Q}_{\mathrm{co}}=\mathrm{h}_{\mathrm{h}} \pi \mathrm{D}_{\mathrm{c}} \mathrm{L}_{\text {rot }}\left(\mathrm{T}_{\mathrm{g}}-\mathrm{T}_{\text {wall }}\right)$

Where $h_{h}$ is the heat transfer coefficient and computed from the follows empirical form [13]:

$\mathrm{h}_{\mathrm{h}}=820 \mathrm{D}_{\mathrm{c}}^{-0.2} \mathrm{P}^{0.8} \mathrm{u}^{0.8} \mathrm{~T}_{\mathrm{g}}^{-0.53}$

\subsection{Discretization scheme and solution procedure}

Two-step Lax-Wendroff scheme is used as a numerical solver to assign the propagation of pressure waves. Using this method, the space-time plane is discretized taking a finite number of nodes $\left(\mathrm{N}_{\text {nodes }}\right)$ in the $\mathrm{x}$-direction (space) while the $\mathrm{t}$ direction (time) is discretized as $\Delta \mathrm{t}$ in a way to satisfy the criteria of stability as described later, as shown clearly in Fig. (5). The space-time grid may also be interpreted as the movement of a cell over the time passing each channel during a complete charging/scavenging cycle. 


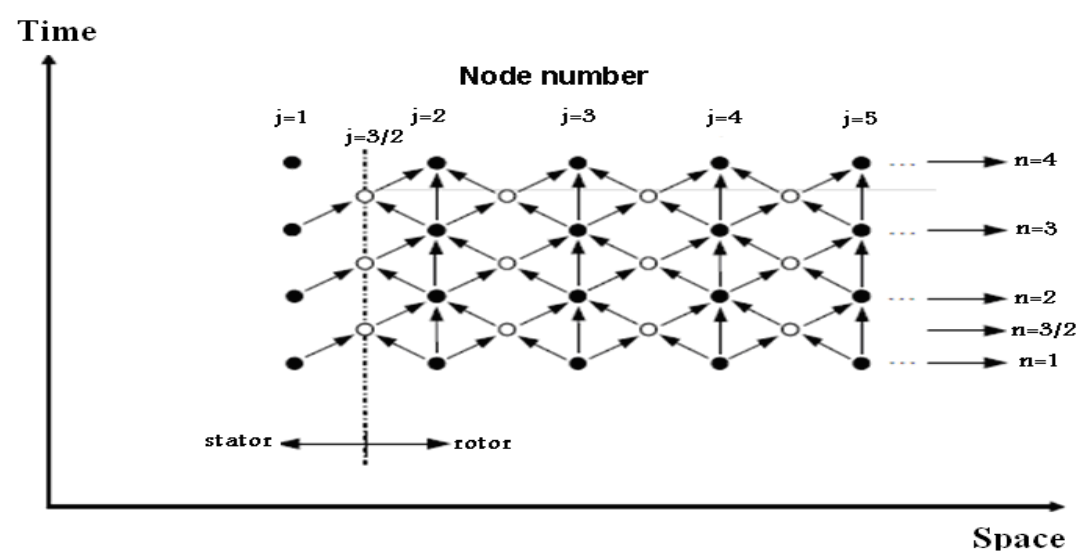

Fig .5 Space-time grid for the two-step Lax-Wendroff scheme

The numerical solver is used to solve equation (2-14) by handling the space-time grid row by row from the bottom $(n=1)$ to the top. This method takes place in two steps .The first step is devoted to compute the intermediate points on level $(n+1 / 2)$. This is expressed numerically by:

$\mathrm{U}_{\mathrm{j}+\frac{1}{2}}^{\mathrm{n}+\frac{1}{2}}=\frac{1}{2}\left(\mathrm{U}_{\mathrm{j}}^{\mathrm{n}}+\mathrm{U}_{\mathrm{j}+1}^{\mathrm{n}}\right)-\frac{\Delta \mathrm{t}}{2 \Delta \mathrm{x}}\left(\mathrm{F}_{\mathrm{j}+1}^{\mathrm{n}}-\mathrm{F}_{\mathrm{j}}^{\mathrm{n}}\right)+\frac{\Delta \mathrm{t}}{4}\left(\mathrm{~B}_{\mathrm{j}+1}^{\mathrm{n}}+\mathrm{B}_{\mathrm{j}}^{\mathrm{n}}\right)$

For the second "Leapfrog" step, equation (2-20) specifies the algorithm for the points on the new level $(\mathrm{n}+1)$

$\mathrm{U}_{\mathrm{j}+1}^{\mathrm{n}+1}=\mathrm{U}_{\mathrm{j}}^{\mathrm{n}}-\frac{\Delta \mathrm{t}}{\Delta \mathrm{x}}\left(\mathrm{F}_{\mathrm{j}+\frac{1}{2}}^{\mathrm{n}+\frac{1}{2}}-\mathrm{F}_{\mathrm{j}-\frac{1}{2}}^{\mathrm{n}-\frac{1}{2}}\right)+\frac{\Delta \mathrm{t}}{2}\left(\mathrm{~B}_{\mathrm{j}+\frac{1}{2}}^{\mathrm{n}+\frac{1}{2}}+\mathrm{B}_{\mathrm{j}-\frac{1}{2}}^{\mathrm{n}-\frac{1}{2}}\right)$

Where:

$\mathrm{U}, \mathrm{F}$, and $\mathrm{B}$ are defined previously. The spatial distance $\Delta \mathrm{x}$ is identified by the rotor length and the specified number of grid points $\mathrm{N}_{\text {nodes }}$ in the space direction. While time step $\Delta \mathrm{t}$ in the time coordinate has to be assigned to satisfy the criteria of stability.

$$
\Delta \mathrm{x}=\frac{\mathrm{L}_{\text {rod }}}{\mathrm{N}_{\text {nodes }}-1} \quad \Delta \mathrm{t}=\frac{\Delta \mathrm{x} \cdot \mathrm{CFL}}{\mathrm{a}}
$$

Where: (Courant number) $\mathrm{CFL}<1$ and $\mathrm{a}$ is the speed of sound. In the presented model the simple and efficient method of artificial viscosity is used[6] to enhancing the instability of solution. The vector $U$ is then modified in a third step as follows:

$$
\mathrm{U}_{\mathrm{j}}^{\mathrm{n}+1}=\mathrm{U}_{\mathrm{j}}^{\mathrm{n}+1}+0.25 \beta\left(\mathrm{U}_{\mathrm{j}+1}^{\mathrm{n}+1}-2 \mathrm{U}_{\mathrm{j}}^{\mathrm{n}+1}+\mathrm{U}_{\mathrm{j}-1}^{\mathrm{n}+1}\right)_{(2-}
$$

Where $\beta$ is the artificial viscosity $1 \geq \beta \geq 0$ and the best results were found to be where $\beta=0.6$ [6].

\subsection{Boundary conditions.}

The nonlinear elliptic, partial differential equation representing conservation equations are solved together iteratively.

The flow domain inside the rotor channels at the first time step is completely defined as well as at boundaries. The port timing is essential to represent the flow conditions at boundaries which can be summarized as follows:

- Closed wall boundaries (where both ends are closed), where no flow (exhaust gases and air) inlet or outlet from the cell.

-Discharge/ charging condition (where any port becomes opened)

The exhaust gases enter from ch3 or GPV (Fig.(1)) and air from ch1 in charging process. The compressed air leaves the cell in discharging process toward the engine intake manifold. Also in this process the exhaust gases and the air still in the cell leaves it toward ch4 in scavenging process. (In all cases, the effective cross section area at inlet or outlet is considered).

\subsection{Validation of numerical model}

In this section, the output results are compared with measured data of PWS engine systems to validate the present model [13]. The measured pressure at each port (air/gas inlet/outlet channel), is compared with pressure calculated from the present model data. However, in his model the exhaust pressure as a boundary condition is considered constant. The measurements were taken from test bench engine equipped with the Hyprex PWS (SAB360/CX64) which have the following specifications:

Displaced volume $=358 \mathrm{ccm}$, Stroke $=54 \mathrm{~mm}$, number of cylinders $=2$, wave rotor length $\&$ diameter $=64 \mathrm{~mm}$ and peak power $=40 \mathrm{~kW}$.

After three PWS cycles, the simulated pressure values correspond to the measurement results with an error of less than $8 \%$ as shown in Table(1). 
A. H. El-Askary, S. A.Wilson, A.R .Syam, K.A.Omara "Theoretical Investigation Into A Pressure ..."

Table1. Model validation for SAB360/CX64 engine system

\begin{tabular}{ccc}
\hline Charging pressure measured (bar) [13] & Charging pressure calculated (bar) & Error \% \\
\hline 2.1 & 1.99 & 5.23809 \\
1.759 & 1.7 & 3.35417 \\
1.6 & 1.53 & 4.375 \\
1.14 & 1.22 & 7.01754 \\
\hline
\end{tabular}

\section{Results and discussion}

During the charging process, the pressure at boundaries varies with respect to time. This in turn governs the flow direction and pressure wave's propagation inside the wave rotor. In the present study the source of pressure wave at $\mathrm{ch}_{3}$ depends on pulsated pressure of the exhaust manifold. The PWS completes its cycle in half time of exhaust gas stroke when rotate at speed 1200rpm. Figures (6 and 7) represent the propagation of pressure wave front with respect to time through $\mathrm{ch}_{3}$. It seems as a compression wave. By the end of blow down process, the exhaust pressure becomes quasi steady and somewhat greater than the atmospheric pressure as show in Fig.(4). Consequently pressure drop will be noted as shown in Figures (6 and 7). This will happen due to the decrease in the pressure source at exhaust gas side. Due to the pressure waves coming from the exhaust gases the fresh air is compressed to $\mathrm{ch}_{2}$ which feed inlet manifold of engine by compressed fresh air. The pressure waves transmitted to fresh air side at $\mathrm{ch}_{2}$ will be introduced to the inlet manifold to charge the engine as shown in Fig. (8). After a short period the exhaust gas enthalpy is transmitted to the fresh air and the pressure inside the cell will decrease.

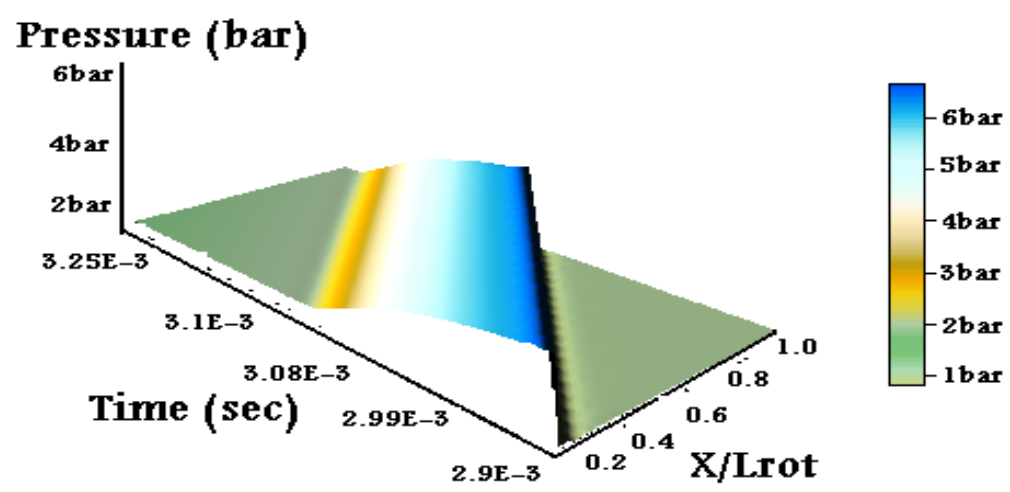

Fig.6 Pressure waves propagation through $\mathrm{ch}_{3}$ at speed 1200rpm.

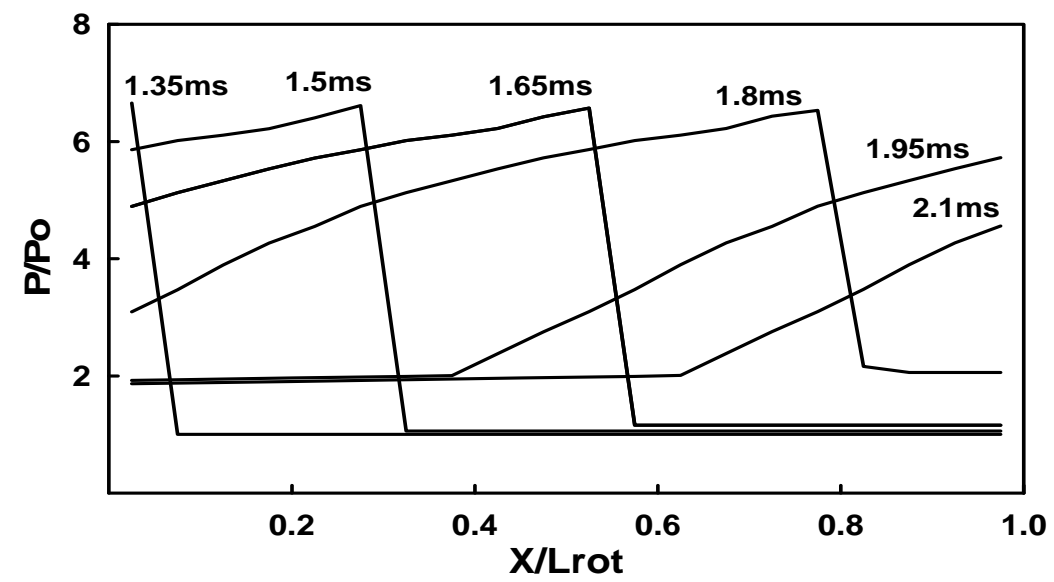

(a)First charging cycle (blow down process) 
A. H. El-Askary, S. A .Wilson, A .R .Syam, K.A.Omara "Theoretical Investigation Into A Pressure ...”

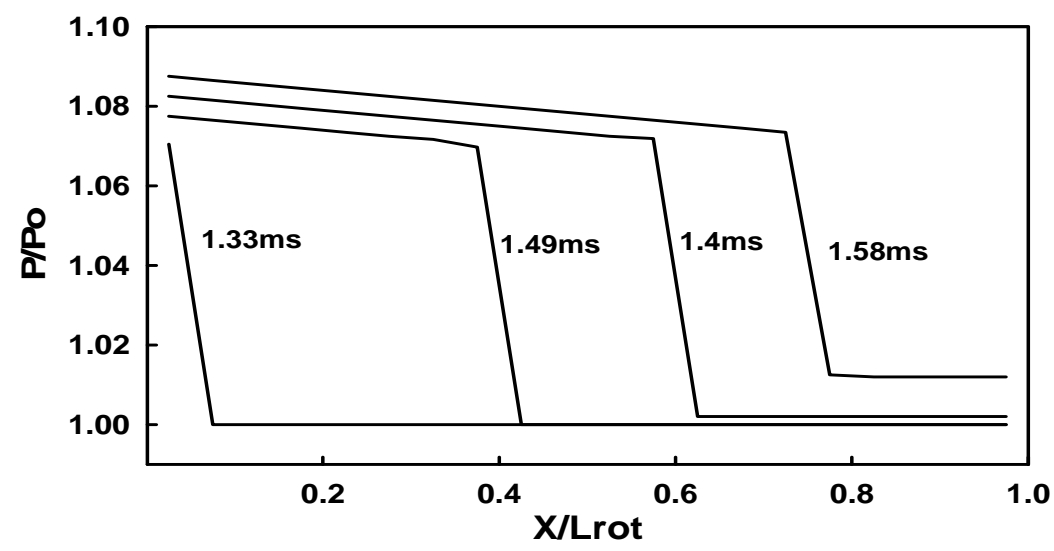

(b)Second charging cycle (steady exhaust period)

Fig .7 Spatial pressure distribution at each time step in $\mathbf{c h}_{3}$

The (GPV) is used in this case to help in scavenging the exhaust gases and part of the fresh air which still in cell to move toward $\mathrm{ch}_{4}$. Fig.(9) represents the propagation of pressure wave front with respect to time through GPV. Spatial pressure distribution at each time step in GPV is shown in Fig.(10) in first and second stage. When exhaust gases inter the cylinder from GPV the enthalpy of residual gases will increase and move toward $\mathrm{ch}_{4}$.

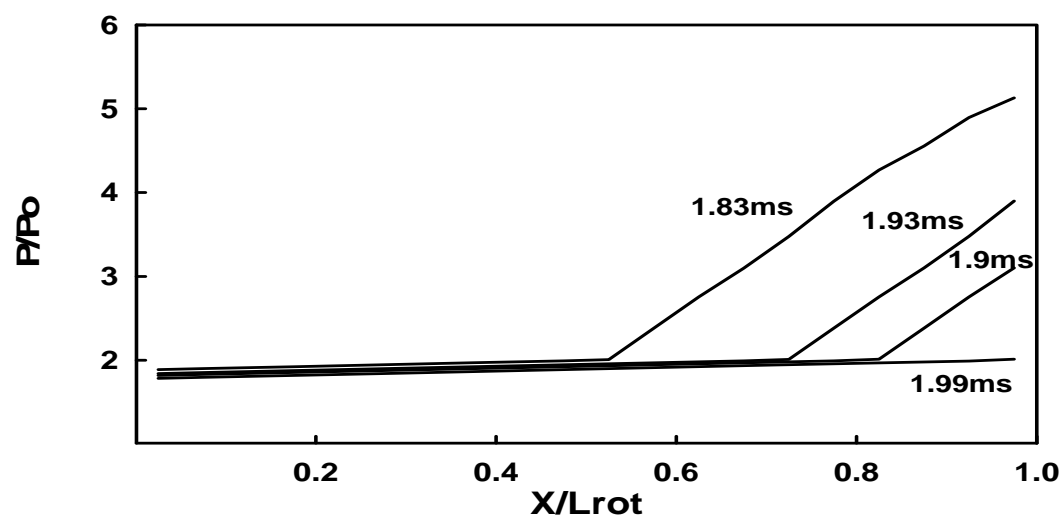

(a)First charging cycle

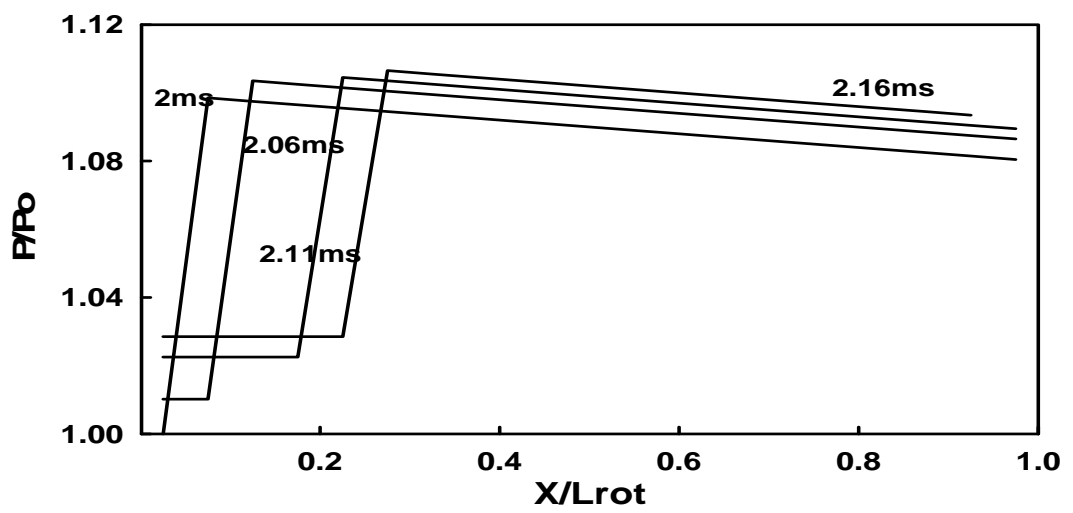

(b)Second charging cycle

Fig.8 Spatial pressure distribution at each time step in $\mathrm{ch}_{2}$

According to pressure wave transmission from exhaust gases to fresh air on the other side of the cell, amount of air at intake manifold is increased. The mass flow rate of fresh air is computed at every time 
step. Also the mass accumulation is calculated to evaluate the volumetric efficiency of engine. The results show a remarkable increase in the volumetric efficiency. Fig (11) shows the mass accumulation of air leaving the cells to the plenum before intake valve opens. If the PWS speed is slow enough, part of exhaust gases reaches the charge port and exhaust species appear in the fresh charge. When increasing the PWS speed, the charge cycle becomes shorter at which the diffusion of exhaust gases cannot reach the charge port as shown in Fig (12).

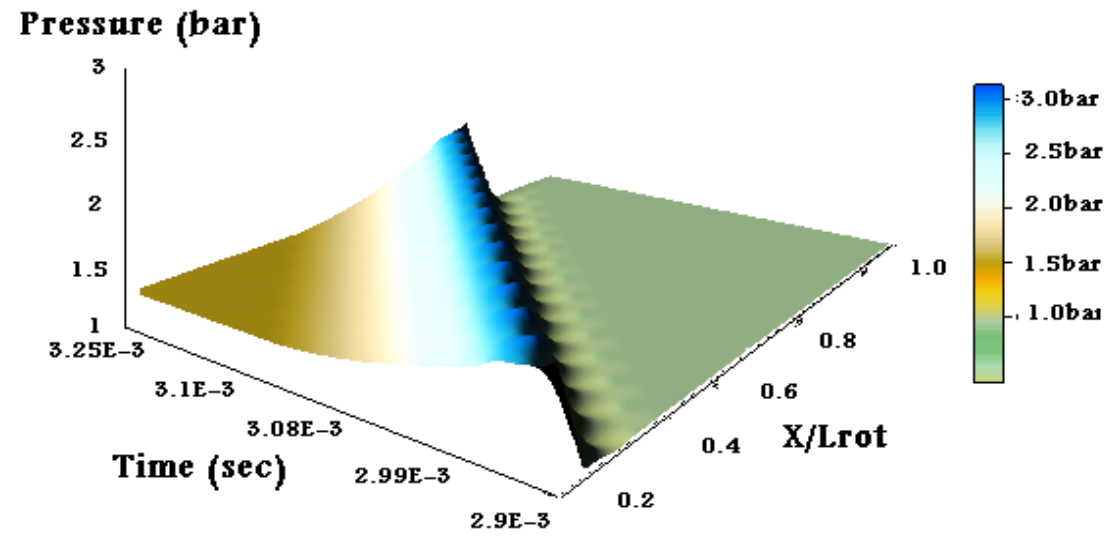

Fig. 9 Pressure waves propagation in GPV

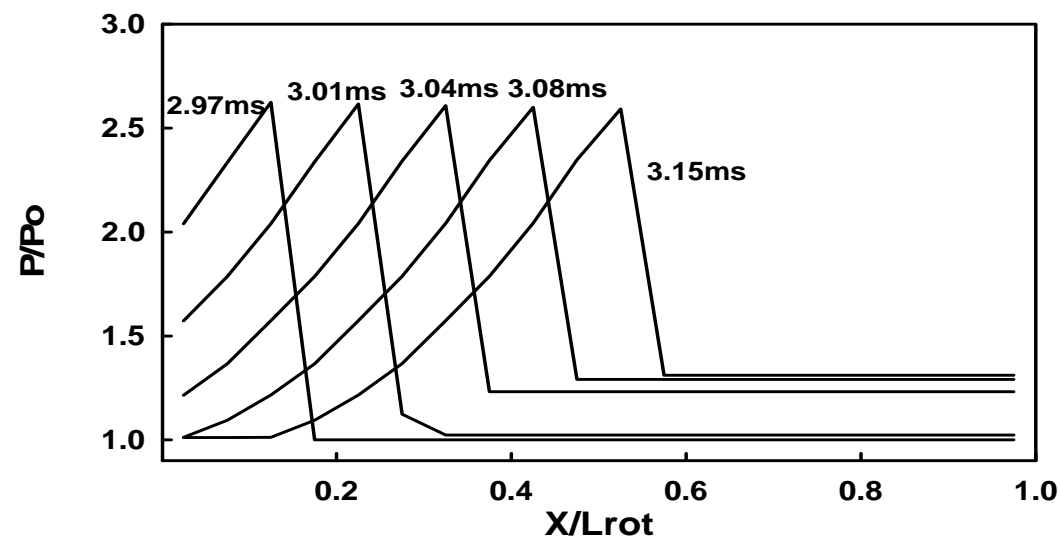

(a)First cycle of exhaust

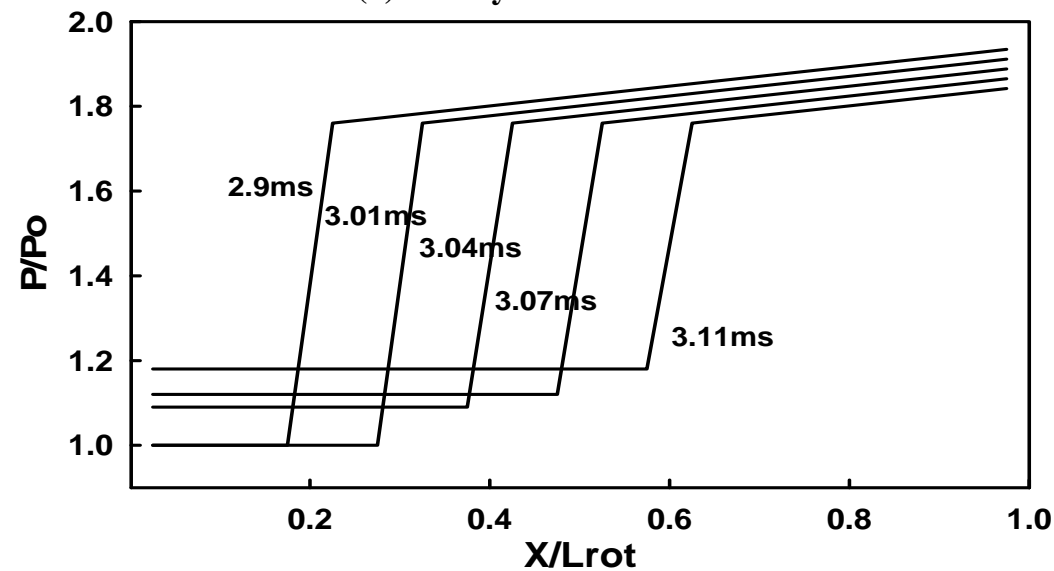

(b)Second cycle of exhaust

Fig.10 Spatial pressure distribution at each time step in GPV

The amount of the exhaust gases entering the engine (EGR) will be decrease as the PWS speed increase until it is vanished at $13500 \mathrm{rpm}$ as shown in Fig.(12). Where emissions are a key element in this study had to be taken into account. $\mathrm{NO}_{\mathrm{x}}$ emissions were calculated to make sure that the present code success to reduce it. The $\mathrm{NO}_{\mathrm{x}}$ emission increased as a result of increasing the temperature inside the engine. 
Fig.(13) shows the relationship between $\mathrm{NO}_{\mathrm{x}}$ emission and temperature inside the engine. Also shows the variation of $\mathrm{NO}_{\mathrm{x}}$ with engine speed. Finally, improving performance of the engine was observed as a result of the use of PWS. Fig. (14) shows the increase in compression ignition engine power capacity due to charging effect. Also, the figure shows the increase in the power and the volumetric efficiency to increasing the speed of the charger.Also; it can observe that the power ratio increases by $8 \%$ and volumetric efficiency by $65 \%$ when the PWS speed changes from 9000 to 14000 rpm due to increasing amount of air which charged to engine

PWS.

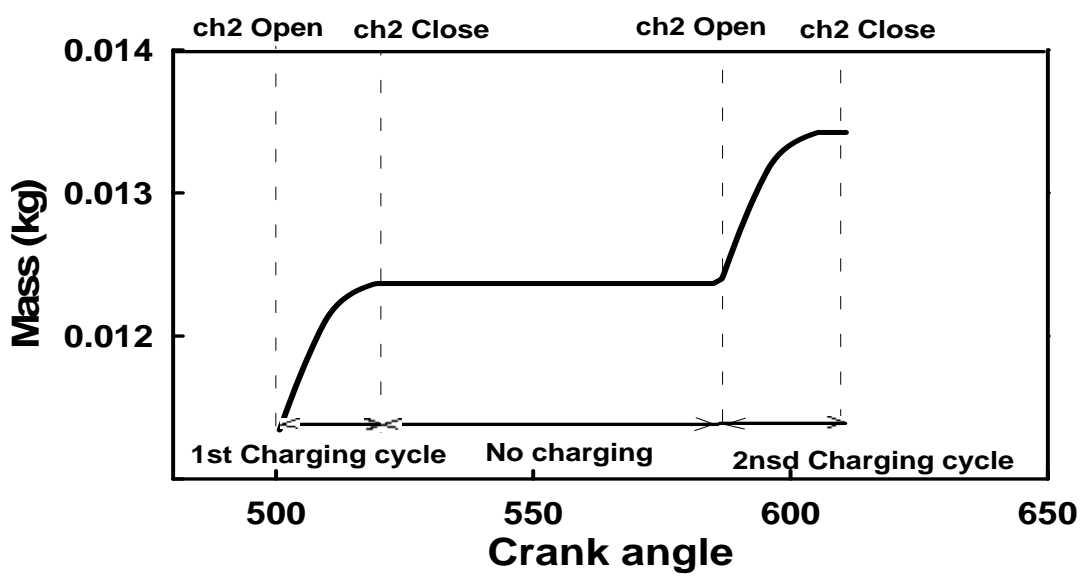

Fig.11 Accumulation mass of air in plenum

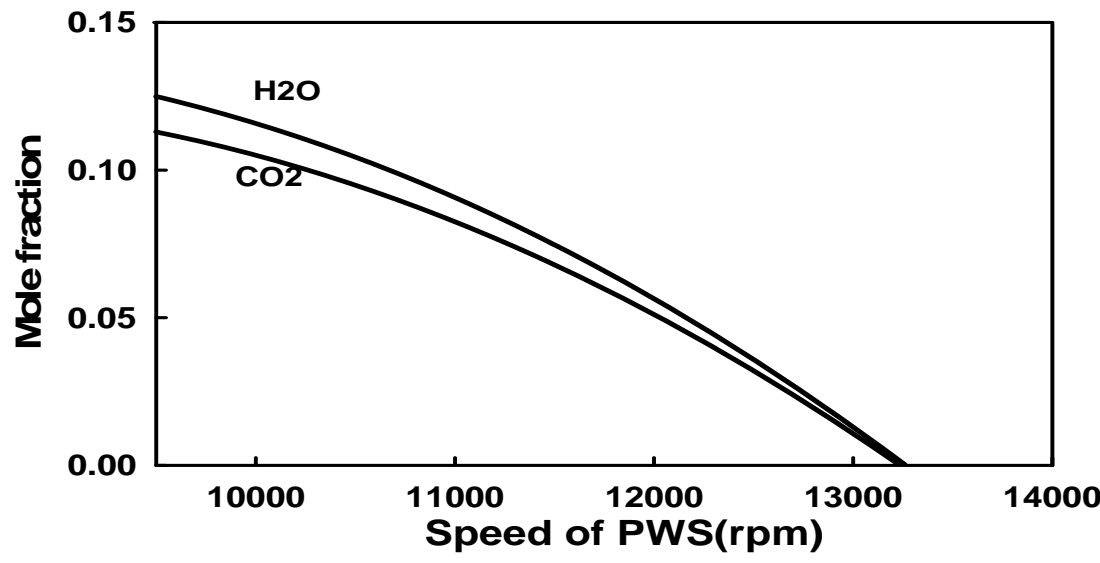

Fig.12 Mole fraction of exhaust gases at charging point

\section{Conclusion}

The present work introduces an itemized explanation for using the PWS with the compression ignition engines (CIE). The PWS's dimensions, number of cells and the rotation speed were accurately selected. This design makes it possible to study the wave's propagation and transmitting through the PWS. In the present proposed model the gas flow is treated as one dimensional, time dependent and non-reactive compressible flow. Some factors were taken into account such as; gas leakage through rotor clearance, exhaust heat losses and friction losses. The possible flow conditions at boundaries were described as closed wall boundaries, discharge conditions and charging conditions. In these cases, the effective cross section area at inlet and outlet is considered. The diffusion between the exhaust gases and the air was considered to estimate the value of exhaust gas recirculation (EGR). Two step Lax-Wendroff scheme numerically used to solve this model. The model also includes solving of engine thermodynamic cycle to get exhaust gases that will be the source of the pressure waves. It is obvious in this study that synchronization between the engine speed (3000 $\mathrm{rpm})$ and the PWS speed (12000 rpm) was made in a closed cycle. The results of this program were compared and accepted. The error was in the permissible limits. 

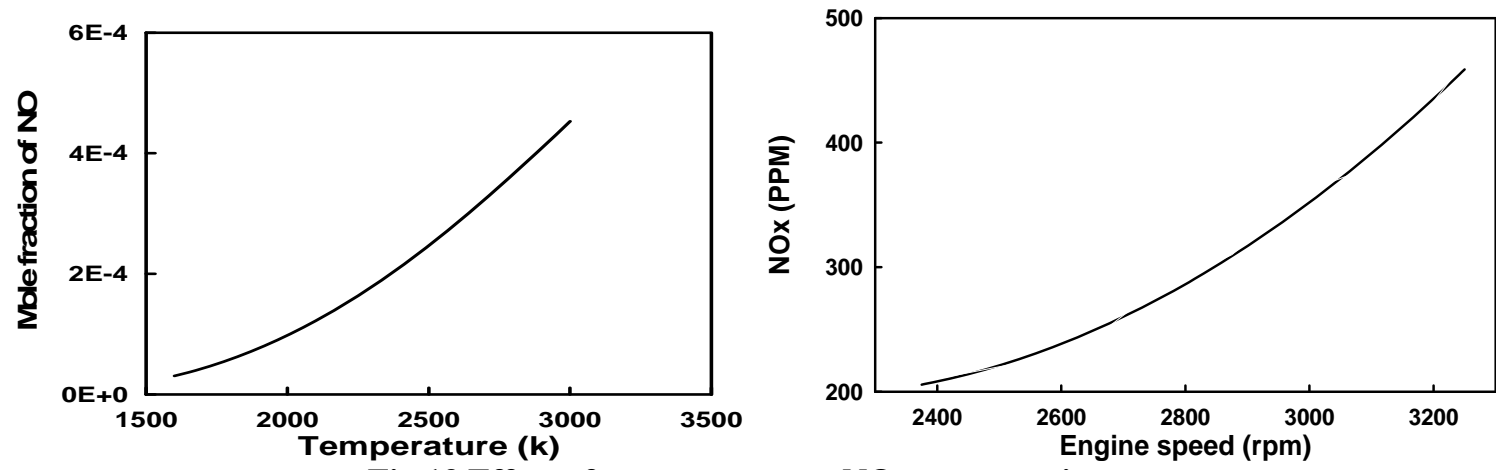

Fig.13 Effect of temperature on NO concentration
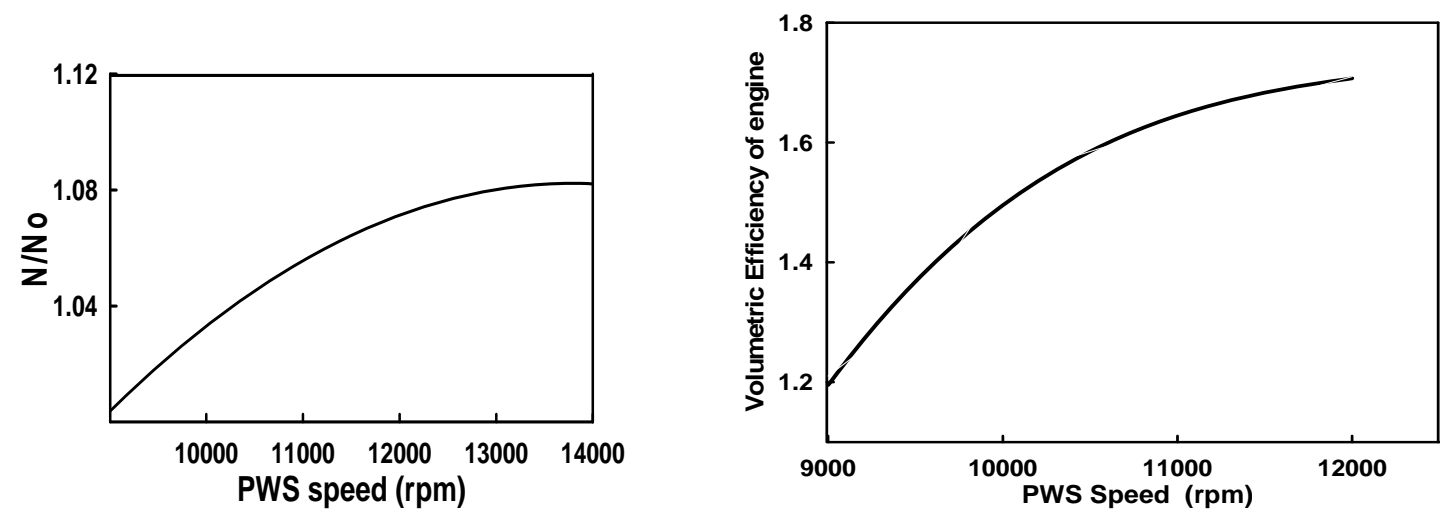

Fig.14 Effect of PWS speed on engine power ratio.

Finally, it can conclude that using the PWS with the compression ignition engines leads to:

-The design of opening and closing ports of PWS is essential in controlling the amplitude of waves and their reflection inside the cell of PWS.

-Increasing the volumetric efficiency by $65 \%$ as natural aspirated engine and power ratio of the engine by $8 \%$.

\section{Nomenclature \\ Abbreviations \\ CFL \\ CIE \\ EGR \\ GPV \\ NO \\ PWS \\ Courant number \\ Compression-ignition engine \\ Exhaust gas recirculation \\ Gas pocket valve \\ Nitrogen oxides \\ Pressure-wave supercharger}

$\begin{array}{ll}\text { Subscript } & \text { Description } \\ \mathrm{c} & \text { Cell } \\ \mathrm{ch} & \text { Channel } \\ \mathrm{fr} & \text { Friction } \\ \mathrm{le} & \text { Leakage } \\ \mathrm{r} & \text { (PWS) rotor } \\ \mathrm{co} & \text { Convection } \\ \mathrm{rpm} & \text { Revolutions per minute }\end{array}$

-Decreasing the emissions of $\mathrm{NO}_{\mathrm{x}}$ by $422 \mathrm{PPM}$ as a result of increasing EGR by $20 \%$ in the charging mass flow rate of engine.

-At high speed of PWS (13500rpm) EGR is vanished.

-Synchronization between engine speed and PWS speed is very important for improving the ICE performance and emissions.

\section{Symbol}

A

$(\mathrm{A} / \mathrm{F}) \mathrm{s}$

Description

a

$$
\text { Speed of sound }(\mathrm{m} / \mathrm{s})
$$

Cross-section area $\left(\mathrm{m}^{2}\right)$

Stoichiometric air-to-fuel ratio (-)

$\begin{array}{ll}\mathrm{A} / \mathrm{A}_{\mathrm{o}} & \begin{array}{l}\text { Ratio of effective area to total area } \\ \text { of the cell }(-)\end{array} \\ \mathrm{B} & \begin{array}{l}\text { Vector of source terms }\left(\mathrm{kg} / \mathrm{m}^{3} \mathrm{~s} ;\right. \\ \left.\mathrm{kg} / \mathrm{m}^{2} \mathrm{~s}^{2} ; \mathrm{kg} / \mathrm{ms}^{3}\right)\end{array} \\ \mathrm{c}_{\mathrm{p}} & \begin{array}{l}\text { Constant pressure specific heat } \\ (\mathrm{J} / \mathrm{kg} . \mathrm{K})\end{array} \\ \mathrm{c}_{\mathrm{v}} & \begin{array}{l}\text { Constant volume specific } \\ \text { heat }(\mathrm{J} / \mathrm{kg} . \mathrm{K})\end{array} \\ \mathrm{C}_{\mathrm{fr}} & \begin{array}{l}\text { Friction coefficient }(-) \\ \mathrm{CA}\end{array} \\ \text { Crank angle (degree) }\left(^{\circ}\right) \\ \mathrm{r}_{\mathrm{in}} & \text { Inner radius of the cell }(\mathrm{m})\end{array}$


A. H. El-Askary, S. A.Wilson, A.R .Syam, K.A.Omara "Theoretical Investigation Into A Pressure ..."

\begin{tabular}{|c|c|c|c|}
\hline$r_{\text {out }}$ & Outer radius of the cell $(\mathrm{m})$ & $\mathrm{P} / \mathrm{Po}$ & $\begin{array}{l}\text { Pressure ratio (pressure inside the } \\
\text { cell to atmospheric pressure) }\end{array}$ \\
\hline$\Delta \mathrm{t}$ & Time step (-) & Q & Heat transfer $(\mathrm{J})$ \\
\hline & & $\overline{\mathrm{U}}$ & Vector of conservative variables \\
\hline $\mathrm{e}_{\mathrm{T}}$ & Specific total energy $(\mathrm{J} / \mathrm{kg})$ & & $\left(\mathrm{kg} / \mathrm{m}^{3} ; \mathrm{kg} / \mathrm{m}^{2} \mathrm{~s} ; \mathrm{kg} / \mathrm{ms}^{2}\right)$ \\
\hline$f_{\text {fr }}$ & Specific friction $\left(\mathrm{m} / \mathrm{s}^{2}\right)$ & $\mathrm{u}$ & Velocity $(\mathrm{m} / \mathrm{s})$ \\
\hline $\mathrm{H}$ & Enthalpy $(\mathrm{J})$ & $\mathrm{X} / \mathrm{L}_{\mathrm{rot}}$ & Ratio of effective length to total \\
\hline$h_{h}$ & Heat transfer coefficient $\left(\mathrm{W} / \mathrm{m}^{2} . \mathrm{K}\right)$ & & length $(-)$ \\
\hline $\mathrm{L}$ & Length $(\mathrm{m})$ & $\mathrm{x}$ & Spatial dimensions $(\mathrm{m})$ \\
\hline $\mathrm{K}$ & Polytrophic index(-) & $\beta$ & Artificial viscosity parameter (-) \\
\hline M & Momentum (N.m) & & \\
\hline $\mathrm{n}$ & Rotational speed (rpm) & $\rho$ & Density $\left(\mathrm{kg} / \mathrm{m}^{3}\right)$ \\
\hline N/No & $\begin{array}{l}\text { power ratio of supercharged engine } \\
\text { to naturally aspirated engine }\end{array}$ & $\partial$ & Partial derivative (operator) (-) \\
\hline $\mathrm{p}$ & Pressure $(\mathrm{Pa})$ & $\lambda$ & Excess air factor (-) \\
\hline
\end{tabular}

\section{REFERENCES}

[1]. Weber, F. and Guzzella, L. (2000). "Control Oriented Modeling of a Pressure Wave Supercharger". SAE Technical Paper, 2000-01-0567.

[2]. Doerfler, P. (1975). "Comprex Supercharging of Vehicle Diesel Engines". SAE Paper 750335.

[3]. Gyarmathy, G. (1983). "How does the Comprex Pressure-Wave Supercharger Work"SAE Technical Paper, 830234

[4].Mayer, A. (1988). "Comprex-Supercharging eliminates Trade-off of Performance", Fuel Economy and Emissions. SAE Technical Paper Series 881152 August 8-11.

[5].Spring, P., Guzzella, L., and Onder, C. (2003)." Optimal Control Strategy for a Pressure-Wave Supercharged SI Engine". Technical Paper ICES2003-645, Proceedings of ICE03, 2003 spring Technical Conference of the ASME Internal Combustion Engine Division, Salzburg.

[6]. Spring, P., Piechna, J., and Onder, C. (2004)." Modeling and Validation of aPressure-wave Supercharger using a Finite-difference Method". 2004 International Mechanical Engineering Conference, Anaheim, CA, ASME Paper IMECE2004-59533.

[7]. Hewedy, N.I.I, Badrah, S. M, Nasr, M. and Hegab, A.M (1992)."Qusai-steady and unsteady flow analysis for moving rarefaction wave in variable cross- sectional area ducts" Fourth international conference of fluid mechanics- Alexandria.

[8]. Paxson, D.E.: (1992)"A General Numerical Model for Wave Rotor Analysis",NASA TM105740, Cleveland.

[9]. Paxson, D. E. (1995a). "Comparison between Numerically Modeled and Experimentally Measured Wave-Rotor Loss Mechanisms". Journal of Propulsion and Power, 0748-4658, Vol. 11 No. 5, pp. 908-914.

[10]. Piechna, J.: "Comparison of different methods of solution of Euler equations in Application to Simulation of the Unsteady Processes in Wave Supercharger". Arch. Mech. Eng. XLV(2), 87-106, Warsaw, Poland (1998).

[11]. Piechna, J.: "Numerical Simulation of the Comprex Type of Supercharger: Comparison of Two Models of Boundary Conditions". Arch. Mech. Eng. XLV(3), 233-250, Warsaw, Poland (1998).

[12]. Piechna, J.: "Numerical Simulation of the Pressure Wave Supercharger Effect of Pockets on the Comprex Supercharger Characteristics". Arch. Mech. Eng.XLV(4), 305-323, Warsaw, Poland (1998).

[13]. Podhorelsky, L., Macek, J., Polasek, M., Vitek, O.: "Simulation of a Comprex Pressure Exchanger in 1-D Code". In: 2004 SAE World Congress, SAE 04P 241, Detroit (2004)

[14]. Jack Wilson., Gerard E. Welch., Daniel E. Paxson. "Experimental Results of Performance Tests on a Four-Port Wave Rotor". NASA/TM-2007214488 
A. H. El-Askary, S. A.Wilson, A.R .Syam, K.A.Omara "Theoretical Investigation Into A Pressure ..."

[15]. Florin Iancu · Janusz Piechna.: "Basic Design Scheme for Wave Rotors". 11 July 2008. SpringerVerlag (2008).

[16]. Akbari, P., Nalim, R., and M“uller, N. (2004). "A Review of Wave Rotor Technology and its Applications". 2004 ASME International Mechanical Engineering Conference, Anaheim, CA, ASME Paper IMECE2004-60082. 